\title{
Influence of Coastal Atmosphere in the Corrosion of Components in Metallic Structures of Cuban Telecommunications Company (ETECSA) in Ciego de Avila, Cuba
}

\author{
Wilman Pereiro Fuentes ${ }^{1}$, Nancy de la Caridad García Álvarez ${ }^{2}$ and Antonio Daquinta Gradaille ${ }^{3}$ \\ ${ }^{1}$ Cuban Telecommunications Company (ETECSA) \\ Ciego de Avila, Cuba. \\ Email: wilman.pereiro [AT] nauta.cu \\ ${ }^{2}$ University of Ciego de Ávila Máximo Gómez Báez (UNICA) \\ Ciego de Avila, Cuba \\ Email: nancygarcialvarez [AT] gmail.com \\ ${ }^{3}$ University of Ciego de Ávila Máximo Gómez Báez (UNICA) \\ Ciego de Avila, Cuba \\ Email: adaquinta [AT] unica.cu
}

\begin{abstract}
Atmospheric corrosion of metals is an electrochemistry discontinuous process, which occurs only when the metal surface is wet or damp with various weather phenomena as rain, condensation, fog and other. NaCl is identified as one of the most aggressive pollutants for atmospheric corrosion to occur in coastal environments. Weather conditions in Cuba, together with its configuration and geographic location allow that the influence of the marine aerosol arrived to almost all the national territory favoring notably the deterioration of materials, especially the metallic ones. For this reason, it was decided to carry out a preliminary study of the effect of the coastal atmosphere on the corrosion of the components in metallic structures AT-60 and Najasa models of the Cuban Telecommunications Company (ETECSA) in Ciego de Ávila, Cuba. The selected components were subjected to micro and macro analysis. The coexistence of the loss of the paint layer with the onset of pitting corrosion was evidenced in the images observed by microscopy, while the results of the macro analyzes, only for components of the AT-60 model showed affectations, after one year of exposure, with decreases in the thickness of the metalbetween 50 and 100\%, a loss of mass of 18.3\% and perforations due to pitting corrosion that reached a diameter of up to $17 \mathrm{~mm}$ These reasons justified the need of a particular maintenance managementin these zones.
\end{abstract}

Keywords----- Atmospheric corrosion, air pollutants, pitting corrosion, speed of corrosion, tropical climate

\section{INTRODUCTION}

It is known that the atmo spheric corrosion of metals is an electrochemistry discontinuous process, which occurs only when the metal surface is wet or damp with various weather phenomena such as rain, condensation, fog and other, although the magnitude of atmospheric corrosion would be relatively low, were it not for the presence of certain pollutants in the atmos phere [1].

Authors dedicated to the study of corrosion [2-8] demonstrated that different metals exposed to coastal atmosphere increases the speed of this process much more than if they were influenced by another type of atmosphere; $\mathrm{NaCl}$ was identified as an atmospheric pollutant of the most aggressive for corrosion to occur. This salt is incorporated from the sea being its profound effects near the shore, where air tran sports large amounts and produces a continuous water spray [9] It was, noted further, that the presence of circulating liquid media do through structures, mainly at medium temperatures and different chemical compositions, resulting also highly corrosive under these conditions [2].

This phenomenon is accentuated in island territories such as the Caribbean where, motivated by climate change, there is a trend towards greater aggressivenessin terms of sea penetrations, increased winds and the frequency of rainfall. 


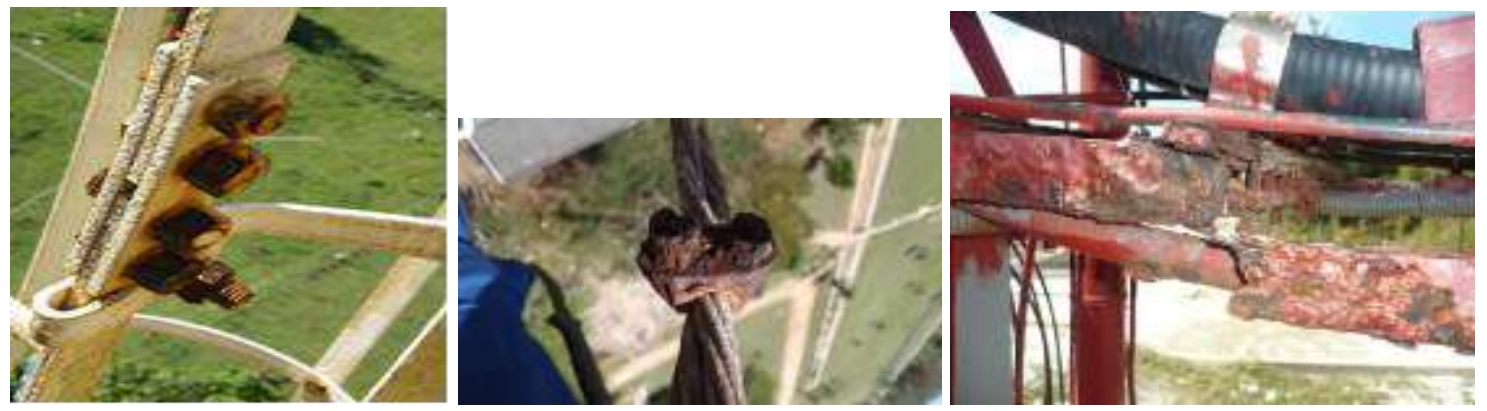

Figure (1): Effects of the coastal atmosphere on the corrosion of components in metal structures

In the particular case of Cuba, the climate is characterized by having more than half the year average temperatures above $25^{\circ} \mathrm{C}$ and average relative humidity of around $80 \%$ [9] which, together with the configuration and geographical location of the country, allows the influence of marine spray to reach almost the entire natio nal territory. These conditions notably favor the deterioration of different materials, especially metallic ones [10]. Figure (1) shows the efects of coastal atmosphere corrosion on the components of the metal structures located in northern of Ciego Avila province.

In ETECSA conditions, no study has been carried out of the effect of the atmosphere, particularly the coastal one, on the corrosion of metal structures and their components located in areas that correspond to that context, which may constitute an aspect negative in the implementation of the maintenance systemestablished by the organization.

This lack led to the realization of this work with the aim of to make a preliminary study of the effect of the coastal atmos phere corrosion of components in the metal structures of ETECSA in Ciego de Ávila.

\section{MATERIAL AND METHODS.}

This work was carried out in ETECSA Ciego de Ávila division, taking as samples certain components of the structures of the AT-60 model, the most widespread in the province, and of the Najasa model, for having this model a large structure that also as sumes the important function of supporting main nodes; both structures located in coastal atmosphere at north of Ciego de Avila province.

To observe the damage caused by corrosion, the samples were subjected to a metallographic analysis (micro level) in a NOVEL eye microscope (Figure 2) from which the corres ponding images were obtained.

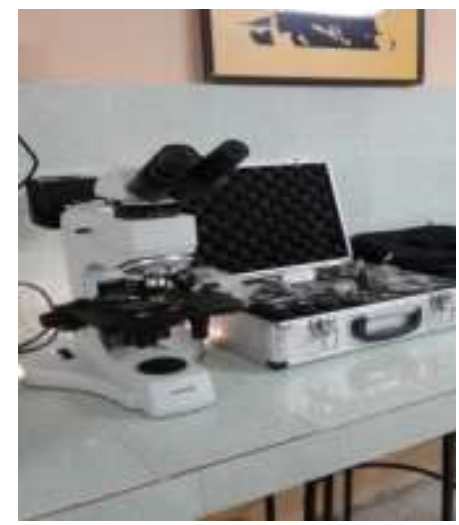

Figure (2): NOVEL brand metallographic microscope or electronic tweeting

For analysis to macro level two plates equalizers of the same type only corresponding to the AT-60 model were taken, one of themunaffected and the other subjected to corrosion in coastal atmosphere for one year. The element for this study was selected due to the importance of its function, since it is responsible for attaching the anchors to the tensions of the different levels of winds or braces to maintain the verticality of the structure. 
In the plates were determined the mas s los s ( $\mathrm{g}$ ) and the thickness loss ( $\mathrm{mm}$ ) of the metal, plus the hole diameter (mm) existing. The obtained values were expres sed in percent.

The thickness of the plates and the diameter of the perforations was meas ured with caliper and mas $s$ with a digital scale modelL4501 BEL with a maximum weighing $4500 \mathrm{~g}$.

The calculations made for the determination of the losses in thickness and mas s of the plates were as follow: Loss of metal thickness $(\%)=\left(\mathrm{E}_{1}-\mathrm{E}_{2} / \mathrm{E}_{1}\right) / 100$

$\mathrm{E}_{1}$ : Initial thickness

$\mathrm{E}_{2}$ : Thicknes s of the corroded part (one year later).

Loss of metalmass $(\%)=\left(\mathrm{m}_{1}-\mathrm{m}_{2} / \mathrm{m}_{1}\right) / 100$

$\mathrm{m}_{1}$ : Initial mas $\mathrm{s}$

$\mathrm{m}_{2}$ : Mass of corroded plate (one year later)

\subsection{Analysis at the micro level}

\section{ANALYSES OF DATA}

The micros tructure of the galvanized coatings was observed in both models, with the objective of examining the morphology of the phases and inters metallic layers formed during the galvanizing.

In Figure (3) it is shown the image corresponding to elements of a circular profile in the AT-60 structure, which reveals the loss in the metal of the paint layer and the appearance of pitting corrosion. Although the objective of this work was focused on the study of the phenomenon in a coastal atmos phere, it was considered important to present the comparis on with another ty pe to highlight the impact caused in the sample submitted to the marine environment. Denote of observation that the mark on the sample taken in coastal atmosphere was greater in size and depth to taken in urban atmosphere.

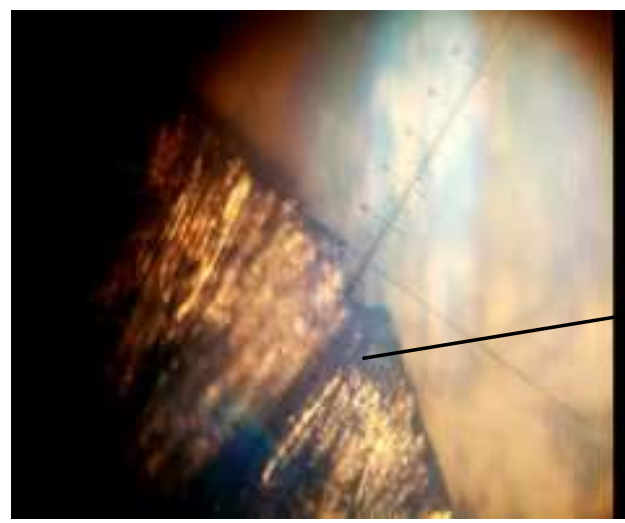

(a) Urban

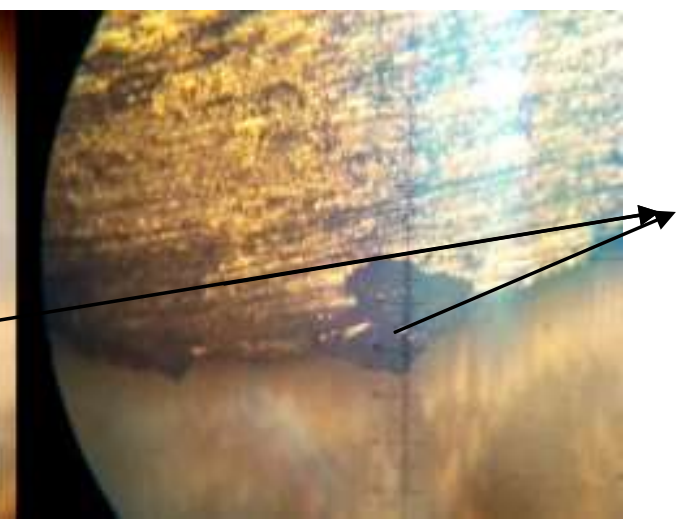

(b) Coastal

Figure (3): Cross section of circular profile elements in structures AT-60 model

In the sample of Najas model(Figure 4) the loss of the galvanized layer, the lack of protection of the metal with the consequent metallic luster and the onset of the formation of urine (oxide layer) detected by the reddish black color were observed. This phenomena shown on theiron surface is due to humidity orair.

Importantly that in both models was detected coexis tence in los s of a portion of the plating layer with the start of pitting corrosion. 


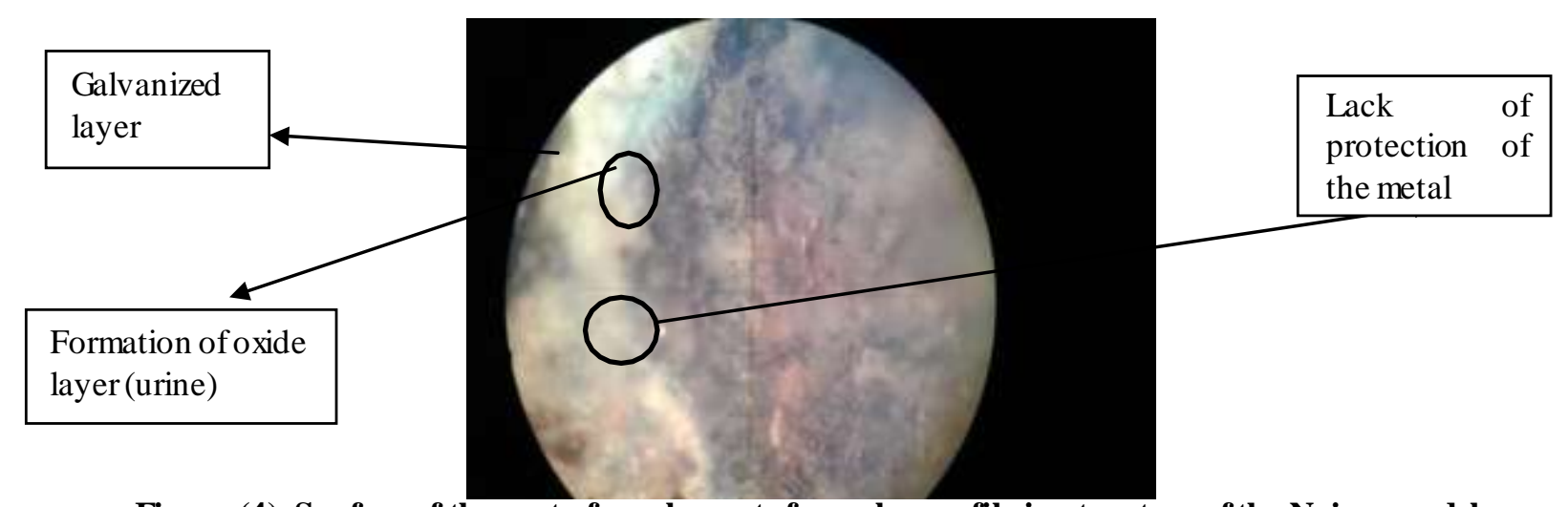

Figure (4): Surface of the part of an element of angular profile in structure of the Najasa model.

\subsection{Analysis at the macro level}

At the macro level, an equalizing plate supported on a model AT-60 structure was analyzed, applying the gravimetric analys is method to determine the los s of thickness $(\mathrm{mm})$ and mas $\mathrm{s}(\mathrm{g})$ and the diameter of the perforations (mm) existing.

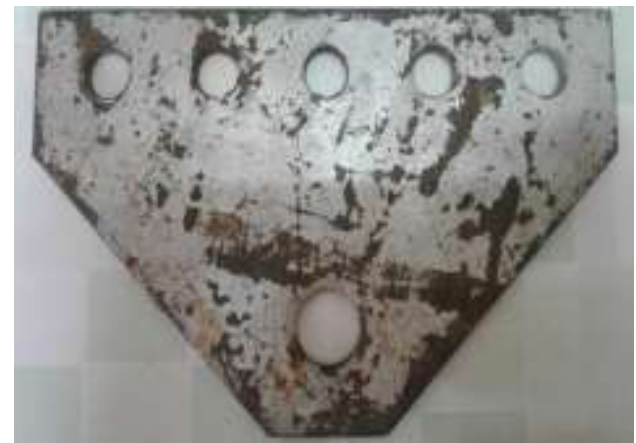

(a) Corrosion-free part

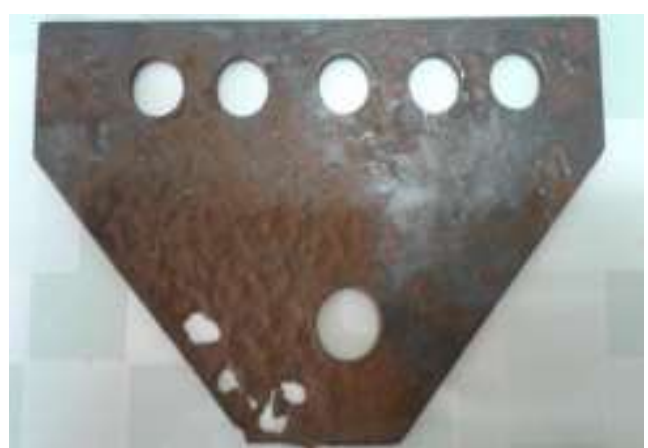

(b) Corroded part

Figure (5): Structure equalizing plate AT-60

For the loss of thickness of the piece, the measurements were made in different places of the piece, since the corrosion does not behave in the same way in all the sections.

Initial thickness: $6 \mathrm{~mm}$ Final thickness varies from 0 to $3 \mathrm{~mm}$ depending on theaffected section.

When the final thickness was $3 \mathrm{~mm}$, the loss corresponded to $50 \%$

When the final thickness was $2.5 \mathrm{~mm}$, the loss corresponded to $58 \%$.

When the final thickness was zero, the loss corresponded to $100 \%$, therefore, it was complete.

The different perforations pitting existing, which are observed in Figure (5b), reached diameters of 9, 12.5, 13 and $17 \mathrm{~mm}$

For the loss of the mass the following results were obtained:

Initial mass: $1,395 \mathrm{~g}$ Final mass: $1,140 \mathrm{~g}$.

Mass loss: $255 \mathrm{~g}$ which corresponded to $18.3 \%$ of the initial mass.

\section{DISCUSSIONOF RESULTS}

The coexistence detected in loss of a portion of the plating layer with the start of pitting corrosion provided an interesting result since although this appearance has much to do with the resistance of steel to corrosion phenomenon [11-13]. Different authors have determined an increasing in the speed of corrosion if the metal is also exposed to a pollutant aggressive as $\mathrm{NaCl}[14,15]$, predominant in coastal atmospheres as it happens in the case of the metallic structures studied. 
In this regard als o[16], had evaluated the corrosion behavior of different galvanized steel products with and without coating, for a humid tropical climate condition in the marine-coastal area of Cojímar in north of Havana, Cuba. The results evidenced the presence of corrosion being exposed to the atmosphere coastal regardless of whether or not they were protected.

Authors [9, 17] when performed micros copic analy zes of the assembly components, in high-voltage transmission towers evaluated in areas with an atmosphere similar to that studied, found an association between the loss thick and the presence of $\mathrm{Cl}$ and $\mathrm{S}$, as predominant pollutants; both form soluble corrosion products in the presence of rain to the continuous dis solving generate a loss of thickness and thus mass. These authors also point out that the situation is aggravated by the direction of the winds, which exert an erosive effect due to the dragging of sand ( $\mathrm{SiO} 2)$ from the beaches. The results of evaluations to the components of the structure AT-60, corroborates this hypothesis.

In the case of ETECSA, for which there is no specific maintenance program, whe re the conditions of the different types of atmosphere in general and of the coastal area in particular are taken into account [18]; it is urgent to carry out the necessary transformations in that sense, which surely benefit the company in terms of a decrease in expenses caused for losses and an increase in the effectiveness of the org anization with the consequent rise in the quality of services.

Is therefore a challenge for design engineers and corrosion experts, the constant study of the engineering st ructures metals and proposed sustainable of actions corrosion protection for them. The results arrived at could constitute a basis to be taken into account for this.

\section{CONCLUSIONS}

Analysis at the micro level allowed determining that the coastal atmosphere influenced a greater corrosive wear of the components in the metallic structures of the AT-60 and Najasa models, beginning the process with the loss of the paint layer and the onset of pitting corrosion.

Macro level analysis showed that after one year of exposure to the coastal atmosphere of a component in the AT60 structure, the thickness of the metal decreased between $50 \%$ and $100 \%$ (complete los s) and perforations were found due to pitting corrosion that reached diameters between 9 and $17 \mathrm{~mm}$, causing a total loss of mass in the metalof $255 \mathrm{~g}$ corres ponding to $18.3 \%$ of the initial mass.

The results in both types of analy sis justify a need to implement maintenance actions immediately the loss of the paint layer is observed, especially in areas where the co astal atmosphere is predominant, which should be considered in management maintenance program.

\section{ACKNOWLEDGEMENTS}

All thanks and appreciation to the staff of Cuban Telecommunications Company (ETECSA) in Ciego de Avila and Faculty of Technician Sciences in University of Ciego de Avila who contributed to the completion of this work.

\section{REFERENCES}

[1] Mocillo, M. (1998). "Predicción a corto y largo plazo de la corrosión atmosférica de metales". Rev. Metal. Madrid, 34.

[2] Chico, B., De La Fuente, D and Mocillo, M. (2000). “Corrosión atmosférica de metales en condiciones climáticas extremas". Bull. Soc. Esp. Glass. 39 (3): 329-332.

[3] Ávila, V., Rodríguez, A.L. and Lías, Y. (2005). "Influencia de los parámetros medioambientales en la corrosión de elementos estructurales metálicos”. Ciencias Holguín, XI (4):1-11.

[4] Martín, Y., Corbo, F., Castañeda, A., Valdés, C., González, E., Pérez J. and Portilla, C. (2007). "Influencia de diferentes factores ambientales en la corrosión de metales que se emplean en la construcción de equipos electrónicos en Cuba”. Revis ta CENIC. Ciencias Químicas. 38(1) 
[5] Monzón, P. (2012). "Determinación de la Velocidad de Corrosión en Armaduras Mediante Técnicas Cuantitativas de Anális is Electroquímico”. M. Sc. (Tes is). Escuela Técnica Superior Ingeniería en Edificación. Univers idad Politécnica de Valencia. España

[6] Lluveras, E.M., Martínez J., González L.C. and Fundora J. A. (2018). "Aplicación de software estadísticos y modelos matemáticos para la evaluación de la velocidad de corrosión en el acero". U.D.C.A Act. \& Div. Scient. 21(1): 179-186.

[7] Restrepo, J. (2018). “La corros ión galvánica, enemiga de las redes de telecomunicaciones”. Cable Servicios (enero 20). Colombia.

[8] Varela-Fernández N. (2016). “Comportamiento mecánico y corrosión marina de diversas aleaciones férricas utilizadas en buques y sus componentes”. PhD (Tesis) Programa de Doctorado de Ingeniería Marítima. Universidad de la Coruña. Es paña. 317 pág.

[9] Rizo, I., Adames, Y and Rivera, Y. (2013). "Es tudio de la corrosión atmosférica del acero al carbono en zonas petrolíferas de la cos ta norte occidental de Cuba”. Revis ta CENIC Ciencias Químicas, 44(1): 216+.

[10] Rivero, S., Chico, B., De la Fuente, D. and M. Morcillo, M. (2007). Corrosión atmosférica del acero bajo en carbono en un ambiente marino polar. Estudio del efecto del régimen de vientos. REV. METAL. MADRID, 43 (5): 370-383

[11] Paredes, S.; Hidalgo, B.; Ávila, R. and Briceño, M. (2007). "Es tudio de la corrosión por picadura de la aleación comercial de aluminio AA3003 en medio ambiente salino". Rev. Téc. Ing. Univ.Zulia 30 (Es pecial). Maracaibo.

[12] Calderón, J.W.,Braga, I.B., Hincapie, D. and Alfonso N. (2015). "Es tudio de la res is tencia a la corrosión por picadura de aceros inoxidables austeníticos: Influencia de la adición de manganeso en solución sólida". Ion, 28(1): 63-72.

[13] Echeverría, C. A., Lage, A., Méndez, O. and Vázquez. Y. (2015). "Influencia del dis eño anticorrosivo en la protección anticorrosiva del área de combustibles de una Central Eléctrica Diesel MTU SERIE 4000". Tecnología Química. 35 (2): 194-207.

[14] Vera, R., Puentes, M., Araya, R., Rojas, P. and Carvajal, A. (2012). "Mapa de corrosión atmosférica de Chile: resultados después de un año de exposición”. Revista de la Construcción. 11(2). Santiago.

[15] Villagran, V.A. (2012). "Estudio de la corrosión de acero al carbono en soluciones salinas de NaCly el efecto de la hidrodinámica". Ing. (Tesis) Facultad de Ciencias Fís icas y Matemáticas. Universidad de Chile. 95 pág.

[16] Suárez X., Villar I., Valentino, R., Corvo F.P. and Marrero R. (2014). "Res is tencia al clima tropical de aceros galvanizados con y sin recubrimiento". Ing. Invest. y Tecnol. 15 (1) México

[17] Romero, B., Minchala, J. M., Angulo, N., Carrasquero, E. and Gil, L. (2019). "Estudio del deterioro corrosivo de componentes de ensamblaje en torres de trasmisión de alta tensión”. CIENCIA y TECNOLOGÍA. 23 (90): 60-71.

[18] Casallas, Q. (2020). “La corrosión en las torres de comunicación”. Inpra Latina. Asociación Nacional de Corrosión de Colombia. (mayo 24). Colombia. 